\title{
A progressive Islamic movement and its response to the issues of the ummah
}

\section{Zuli Qodir}

Universitas Muhammadiyah Yogyakarta

E-mail:zuliqodir@umy.ac.id

Hasse Jubba

Universitas Muhammadiyah Yogyakarta

E-mail:hasse@umy.ac.id

Mega Hidayati

Universitas Muhammadiyah Yogyakarta

E-mail: megahidayati@umy.ac.id

Irwan Abdullah

Universitas Gadjah Mada Yogyakarta

E-mail:irwan.fib@ugm.ac.id
Ahmad Sunawari Long
Universiti Kebangsaan Malaysia
E-mail:aslong@ukm.edu.my
DOI: 10.18326/ijims.v10i2.323-352 


\begin{abstract}
This article aims to discuss the progressive Islamic movement developed by Muhammadiyah, a modernist Islamic organization established by Ahmad Dahlan on November 18, 1918. History has shown that Muhammadiyah, as a modernist Islamic organization, has instigated various social transformations that continue to affect Indonesian society by creating schools, hospitals, and orphanages that were inspired by modern, Westernized systems and modernist interpretations of the Qur'an. Even today, Muhammadiyah remains active in national activities and discourse, continuously responding to the ever-changing times. The data obtained from observations, interviews, and literature studies were analyzed using a discursive-interpretive method where the Islamic movement is regarded as part of the response to various problems of ummah nowadays. This article departs from the argument that the progressive movement developed by Muhammadiyah was translated from Ahmad Dahlan's desire to advance the ummah and to create a just and prosperous world, one that has been blessed by God. The findings of this study indicate that Muhammadiyah's response to the issues of ummah has been informed by the history of the movement and its founders.
\end{abstract}

Artikel ini bertujuan untuk membahas gerakan Islam Berkemajuan yang dikembangkan oleh Muhammadiyah sebagai organisasi Islam modernis yang didirikan oleh Ahmad Dahlan, 18 November 1918. Sebagai organisasi Islam modern, Muhammadiyah telah terbukti dalam sejarahnya membawa pelbagai macam perubahan yang melampaui zamannya. Gerakan yang digagas oleh Ahmad Dahlan mengadopsi sistem pendidikan Barat modern. Mendirikan rumah sakit dan panti asuhan (rumah untuk kaum miskin) merupakan gerakan yang mendapatkan inspirasi dari peradaban Barat modern serta dari tafsir atas teks al-Qur'an secara modern. Muhammadiyah dalam perkembangan hingga saat ini telah bergerak dalam ranah pemikiran dan aktivitas kebangsaan serta keumatan demi menjawab perkembangan zaman yang terus bergerak. Data yang diperoleh dari observasi, wawancara, dan studi pustaka dianalisis menggunakan metode diskursif-interpretif yang melihat gerakan Islam sebagai bagian dari respons terhadap berbagai permasalahan umat saat ini. Artikel ini disandarkan pada sebuah berargumen bahwa gerakan berkemajuan yang dikembangkan Muhammadiyah merupakan wujud nyata dari penterjemahan pemikiran Ahmad Dahlan dengan semangat progresif untuk kemajuan umat manusia di seluruh 
Indonesia dan perkembangan dunia agar menjadi negara yang adil makmur dan sejahtera dalam limpahan karunia Tuhan. Temuan penelitian ini menunjukkan bahwa respons Muhammadiyah atas masalah-masalah keumatan merupakan bentuk nyata dari gerakan berkemajuan yang menjadi ciri khasnya yang memiliki latar belakang historis dari para pendiri persyarikatan.

Keywords: Muhammadiyah; Islamic Movements; Progressive; Religion; Ummah

\section{Introduction}

The Indonesian Islamic movement Muhammadiyah, established in the Yogyakartan villages of Kauman, Kotagede, and Karangkajen, ${ }^{1}$ is recognized as having promoted Islamization in non-Islamic villages ${ }^{2}$ and as curbing the tide of Christianization through its schools and its urban and rural dakwah (proselytization) activities. ${ }^{3}$ Although it helped establish (and quickly left) the Masyumi Party in the 1950s, ${ }^{4}$ Muhammadiyah has primarily contributed to national discourse and development through non-political means. ${ }^{5}$ This has become Muhammadiyah's dilemma in democracy. ${ }^{6}$ Muhammadiyah chose a non practical political path by continuing to provide its cadres to involve in parties and politics. This is a shift in the direction and the practice of Muhammadiyah's politics. ${ }^{?}$

\footnotetext{
${ }^{1}$ Mitsuo Nakamura, The Crescent Arises over the Banyan Tree: A Study of the Muhammadiyah Movement in a Central Javanese Town, c. 1910s-2010: 2nd Enlarged Edition, Singapore: Institute of Southeast Asian Studies, 2012, 51-62.

${ }^{2} \mathrm{M}$. C. Ricklefs, Islamisation and Its Opponents in Java: A Political, Social, Cultural and Religious History, c. 1930 to the Present, Singapore: NUS Singapore, 2012, 11.

${ }^{3}$ Alwi Shihab, Membendung Arus, Respons Muhammadiyah terhadap Penetrasi Kristen di Indonesia, Yogyakarta: Suara Muhammadiyah, 2016, 260-270.

${ }^{4}$ Masyumi = Partai Majelis Syuro Muslimin Indonesia (Council of Indonesian Muslim Associations). See, Saifullah, Gerak Politik Muhammadiyah dalam Masyumi, Jakarta: Grafiti Press, 1997, 190-214.

${ }^{5}$ Saifullah, Pergeseran Politik Muhammadiyah, Yogyakarta: Pustaka Pelajar, 2015, 88-93.

${ }^{6}$ Ahmad Najib Burhani, "Liberal and conservative discourses in the Muhammadiyah: The struggle for the face of reformist Islam in Indonesia”, in Contemporary Developments in Indonesian Islam: Explaining the 'Conservative turn', Martin van Bruinessen (ed.), Singapore: ISEAS \& Yusof Ishak Institute, 2013, 105-144.

${ }^{7}$ Saifullah, Pergeseran Politik Muhammadiyah, Yogyakarta: Pustaka Pelajar, 2015, 88-93.
} 
As the result, in politics, Muhammadiyah chooses a nation politics. ${ }^{8}$ To effect change, it has relied on philanthropy and the provision of social services, establishing schools, hospitals (and other healthcare centers), orphanages, and almshouses. ${ }^{9}$ Muhammadiyah provides its humanitarian services to people of different political affiliations, ethnic backgrounds, and even religious beliefs.

Believing in the purity of Islam, Muhammadiyah seeks to eradicate deviance and syncretism. ${ }^{10}$ In this, it has embraced a modernist-progressive or modernist-reformist ideology, rather than a salafi or jihadi one. Muhammadiyah has thus sought theological reform while still adapting to the changing times. ${ }^{11}$ It is staunchly opposed to the salafi-jihadi ideology that has spread rapidly through Indonesia in recent years. Unlike this ideology, Muhammadiyah does not reject the modern nation-state, but instead embraces those elements that it deems conform to Islamic values. Likewise, Muhammadiyah does not advocate for the passage of shariabased bylaws, nor does it advocate for the broader enactment of sharia. ${ }^{12}$ It is thus ideologically opposed to salafi-jihadi movements, such as Majlis Mujahiddin Indonesia, Hizbut Tahrir Indonesia, Darul Islam-Negara Islam Indonesia, and the wahabi and tarbawi movements that have promoted their own particular form of piety. ${ }^{13}$

${ }^{8}$ Haedar Nashir et al., "Muhammadiyah's Moderation Stance in the 2019 General Election: Critical Views from Within," Al-Jami'ah: Journal of Islamic Studies, Volume 57, Number 1 (June 2019), 1-24.

${ }^{9}$ Hilman Latief, Melayani Umat: Filantropi Islam dan Ideologi Kesejahteraan Kaum Modernis, Jakarta: Gramedia and Maarif Institute, 2010, 191-217.

${ }^{10}$ Haedar Nashir, Memahami Ideologi Muhammadiyah, Yogyakarta: Suara Muhammadiyah, 2014, 3-5.

${ }^{11}$ Nashir, Memahami Ideologi Muhammadiyah..., 42-51.

${ }^{12}$ Haedar Nashir, Islam Syariat: Reproduksi Salafiyah Ideologis di Indonesia, Bandung: MizanMaarif Institute, 2013, 452-478.

${ }^{13} Y u y u n$ Sunesti, Noorhaidi Hasan, and Muhammad Najib Azca, 'Young Salafi-Niqabi and Hijrah: Agency and Identity Negotiation', Indonesian Journal of Islam and Muslim Societies, Volume 8, Number 2 (2018), 173-197. 
As Muhammadiyah is active-not only in Indonesia's cities but also its villages-it exhibits a high level of diversity. Several streams are emergent in Muhammadiyah, including Muhammadiyah al-Ikhlas, Muhammadiyah NU, Muhammadiyah-Marhaen, and Muhammadiyah Dahlanian. ${ }^{14}$ Each of these streams has its own characteristics, and although in some matters they may contrast, they remain part of Muhammadiyah. Since 1995, Muhammadiyah has promoted a discourse that reaches past puritanism, establishing inter-organizational and inter-ideological affiliations as part of a post-puritan movement. ${ }^{15}$ In addition, Muhammadiyah's interpretation in understanding pluralism over the text of the Qur'anic texts tends to be moderate, not textual, after the case of September 11, 2001. ${ }^{16}$ Muhammadiyah has sought to intelligently respond to diverse social, cultural, and political phenomena by advocating particular understandings of what it means to be Muslim. ${ }^{17}$ Owing to its past success, Muhammadiyah is hoped to offer an exemplary means of addressing the problems facing the ummah (i.e. the faithful).

This article seeks to offer authentic proof that Muhammadiyah is a progressive movement, as it is popularly perceived today. Furthermore, this article seeks to determine this Islamic movement's main priorities in dealing with the problems of the ummah. This article uses literature reviews, field observations, and in-depth interviews to collect data, then applies the "new social movement" model to understand this religious movement. According to Rajendra Singh, this model is useful for understanding the

${ }^{14}$ Abdul Munir Mulkhan, Marhaenis Muhammadiyah, Yogyakarta: Galang Press, 2010, 218-221.

${ }^{15}$ Hilman Latief, Post-Ouritanisme: Pemikiran dan Arah Baru Gerakan Islam Modernis di Indonesia, 1995-2015, Yogyakarta: LP3M Universitas Muhammadiyah Yogyakarta, 2017, 18-31.

${ }^{16}$ Mohd Yaseen Gada, "On pluralism, religious 'other', and the Quran: a post September-11 discourse," Indonesian Journal of Islam and Muslim Societies, Vol. 6, No. 2 (2016), 241-71.

${ }^{17}$ Achmadi, Merajut Pemikiran Cerdas Muhammadiyah: Perspektif Sejarah, Yogyakarta: Suara Muhammadiyah, 2010, 107-140. 
social movements that have emerged in the post-modern era as a response to their modernist predecessors.

\section{The Dynamic of Muhammadiyah movement in Indonesia contem- porary era}

As an Islamic movement, Muhammadiyah may be categorized as a new social movement. It is not a sectoral movement that mobilizes the masses to advocate for change, but rather one that addresses humanitarian issues to effect change. ${ }^{18}$ New social movements, particularly in the post-modern era, tend not to focus on material issues-i.e. on conflict over material resources. Rather, they focus on questions of identity and social justice, also commonly known as social grievances, be they at the individual, community, or social level. ${ }^{19}$ In their activities, new social movements may utilize a range of methods, often involving local communities and thereby empowering them. ${ }^{20}$ As such, studies of new social movements in practice must consider issues of humanity and locality in detail. ${ }^{21}$

Muhammadiyah, likewise, is a new social movement that advances a particular agenda and responds to specific strategic issues. In doing so, it utilizes a multi-level structure, with offices from the village through the national level. Its ability to independently respond to the problems of the ummah signifies its strength as a new social movement, and when Muhammadiyah employs its resources optimally, it is unparalleled in

\footnotetext{
${ }^{18}$ Rajendra Singh, Social Movements, Old and New: A Post-Modernist Critique, USA and London: Sage Publication, 2001, 87-134.

${ }^{19}$ Hank Johnston, 'Identities, Grievances, and New Social Movements', in New Social Movements: From Ideology to Identity, Enrique Larana, Hank Johnston, and Joseph R Gusfield (eds.), USA: Temple University Press, 1994, 3-35.

${ }^{20}$ Pamela E. Oliver and Daniel J. Myers, "Formal Models in Studying Collective Actions and Social Movement", in Method of Social Movement Research, Bert Klandermans and Suzanne Staggenborg (eds.), Minnesota: University of Minnesota Press, 2002, 32-61.

${ }^{21}$ Donatella Della Porta, Methodological Practices in Social Movement Research, Oxford: Oxford University Press, 2014, 10-18.
} 
many aspects. However, more often the organization has been unable to fully realize its potential when undertaking its varied activities. ${ }^{22}$ As such, it is necessary to seriously consider the progressive Islamic movement developed by Muhammadiyah using a new social movement framework. Is it true that Muhammadiyah has advanced a progressive Islamic ideology and implemented social programs to better the ummah and respond to their problems?

As a concept, progressive Islam has long been advocated by Muhammadiyah. As shown by Najib Burhani, this concept has been part of the organization since its establishment. ${ }^{23}$ As stated by Omit Shafi, progressive Islam is often understood as reaching "beyond the apologetic," indicating a tolerant Islam, a peaceful Islam. Progressive Islam means no more "pamphlet Islam;" it may thus be concluded that progressive Islam is identified with a strong desire for justice and pluralism within the Muslim community. ${ }^{24}$

Haedar Nashir has discussed progressive Islam more broadly, identifying it as an Islam that understands and actualizes jihad as a means of creating progress, justice, prosperity, dignity, and sovereignty. ${ }^{25}$ Progressive Islam does not understand jihad as a holy war, as inherently necessitating violence, conflict, and enmity; rather, it defines jihad as social struggle, a way to deal with pressing social issues and answer important social questions. In short,

${ }^{22} Z$ Zuly Qodir, "Muhammadiyah Sebagai Gerakan Sosial Baru: Inspirasi Menuju Masyarakat Berkemajuan", in Islam Berkemajuan untuk Peradaban Dunia: Refleksi dan Agenda Muhammadiyah ke Depan, Bandung: Mizan, 2015, 127-140.

${ }^{23}$ Ahmad Najib Burhani, Muhammadiyah Berkemajuan: Pergeseran dari Puritanisme ke Kosmopolitanisme, Bandung: Mizan, 2016, 37-41.

${ }^{24}$ Omid Safi, Progressive Muslims: On Justice, Gender, and Pluralism, London: Oneworld Oxford, 2003, 2.

${ }^{25}$ Haedar Nashir, "Islam Berkemajuan dan Aktualisasi Gerakan Muhammadiyah", in Islam Berkemajuan untuk Peradaban Dunia: Refleksi dan Agenda Muhammadiyah, Bandung: Mizan, 2015, 18. 
it understands jihad as a means of bettering society. ${ }^{26}$ Progressive Islamic movements, such as Muhammadiyah thus seek to address the problems of the ummah, of the nation, and of humanity. ${ }^{27}$

Muhammadiyah understands progressive Islam as originating from within the teachings and doctrines of Islam itself. According to Muhammadiyah, Islam is a religion that utilizes progressive values to advocate for human welfare. From an Islamic perspective, progress is necessary to realize Islam as a blessing for humanity. ${ }^{28}$ More concretely, progressive Islam is understood as dynamically sowing the seeds of truth, goodness, peace, justice, and prosperity, thereby benefiting mankind. It is evident when human beings, men and women alike, are treated as equals. It is evident when Muslims oppose war, violence, subjugation, poverty, and social ills such as corruption, exploitation, crime, and individual/social irresponsibility. In short, progressive Islam seeks to become a positive force, one in which all races, ethnicities, and cultures are embraced as a single people. ${ }^{29}$

To manifest such a progressive Islam in Indonesia and promote social betterment, it is necessary to apply a cultural strategy. The state and the nation must be careful, as any mismanagement will have deleterious effects on generations of Indonesians. As such, progressive Islam must-using a range of approaches-be conceptualized as promoting renewal and reform that is necessary for a better future. Muhammadiyah has advocated for such reform since its establishment, using its discourses and its activities to create social betterment. Central to these activities have been its educational institutions, which have sought to teach students to act independently and wisely as advocates for the downtrodden (mustad'afin). ${ }^{30}$ Muhammadiyah has

\footnotetext{
${ }^{26}$ Nashir, "Islam Berkemajuan"..., 10.

${ }^{27}$ Nashir, "Islam Berkemajuan"..., 11.

${ }^{28}$ Nashir, "Islam Berkemajuan”..., 14.

${ }^{29}$ Nashir, "Islam Berkemajuan"..., 15.

${ }^{30}$ Zuly Qodir, "Kalibokong Theology' and Moeslim Abdurrahman's Transformative Islamic
} 
understood this advocacy as part of its institutional mission, as a means of advancing both the Islamic experiences and expressions of the lower classes. ${ }^{31}$

Muhammadiyah's understanding of progressive Islam may also be understood as tajdid (reformist), as seeking to purify Islam, to avoid causing scientific and technological regression while also eradicating 'Islamic' teachings that are not rooted in the Qur'an and the sunnah. In other words, Islam must not only dynamically adapt to scientific and technological advances, but also maintain a pure doctrine that is clearly rooted in its holy texts. Such reform, as with all reform movements, is oriented towards promoting the greater good and improving human welfare. ${ }^{32}$

Such an argument was also made by Hamim Ilyas, the deputy chairman of Muhammadiyah Central Leadership Committee's Joint Assembly;

"The idea of progressive Islam is derived from the Qur'an and the Sunnah, and used to understand rapidly changing social phenomena. Muhammadiyah cannot simply adhere to existing doctrine without new interpretations that recognize the changing times and technological advances." 33

From this discussion, it may be understood that all of Muhammadiyah's organizational activities cannot be separated from universal humanitarian movements as well as Indonesia's Islamic history. Indonesian Islam has sought to answer the problems that have plagued the Indonesian people and left them struggling in the dark. It is such an Islam that has

Education”, Iseedu: Journal of Islamic Educational Thoughts and Practices, Volume 1, Number 1 (2017), 23--46.

${ }^{31}$ Moeslim Abdurrahman, Suara Tuhan Suara Pemerdekaan, Yogyakarta: Kanisius and Impulse, 2009, 281-289.

${ }^{32}$ Haedar Nashir, Muhammadiyah Gerakan Pembaruan, Yogyakarta: Suara Muhammadiyah, 2010, 287-305.

${ }^{33}$ Original: "Berkemajuan itu merupakan gagasan yang diambil dari semangat al-qur'an dan sunnah makbulah dalam memahami fenomena sosial yang berkembang terus menerus. Muhammadiyah tidak bisa mendasarkan begitu saja dengan doktrin tanpa adanya interpretasi yang mengarah pada kemajuan seperti perkembangan zaman dan teknologi." Interview with Hamim Ilyas, member of the Muhammadiyah Central Leadership Committee's Joint Assembly, on August 12, 2019. 
been advocated by Muhammadiyah and Nahdlatul Ulama, Indonesia's largest Islamic organizations. ${ }^{34}$ Muhammadiyah has borrowed from the rationalist muktazilah school in its implementation of a progressive religious understanding (i.e. theology). Such a rational perspective is not new, having been widely discussed amongst Indonesian Muslim intellectuals advocating a neo-modernist perspective of Islam as a means of responding to modern challenges. ${ }^{35}$ For example, modernist and reform perspectives have been used to curb the growth of fundamentalist theologies. ${ }^{36}$

\section{Progressive Islam as a response to social issues}

For Muhammadiyah, progressive Islam is a means of responding to the problems that have plagued the ummah and the nation. Advocacy, thus, is part of its religious and social responsibility. This can be seen, for example, in the organization's decrees regarding the problems plaguing the ummah and the Indonesian people.

\section{Moderation in diversity}

A moderate religious (Islamic) perspective characterizes "reformistmodernist" Muslims, as distinguished from "integralist" and "secularist" Muslims. Unlike integralists, such as Munawir Sadzjali, who view religion and the state (i.e. formal politics) as inexorably linked, or secularists, who hold that religious affairs must be separated from political affairs (as in the West), modernists argue for the adaptive integration of Islamic values in national politics. Islam must not lay the foundation for the state, nor must it be removed from the state entirely; rather, its values must

\footnotetext{
${ }^{34} \mathrm{Ahmad}$ Syafii Maarif, Islam dalam Bingkai Keindonesiaan dan Kemanusiaan: sebuah Refleksi Sejarah, Bandung: Mizan, 2015, 311-329.

${ }^{35}$ Fauzan Saleh, Teologi Pembaruan: Pergeseran Wacana Islam Sunni di Indonesia Abad XX, Jakarta: Serambi, 2004, 261-303.

${ }^{36}$ Gerrie ter Haar and James J Bussuttil, The Freedom to Do God's Will: Religious Fundamentalism and Social Change, London and New York: Routledge, 2003, 230-235.
} 
provide appropriate guidelines for the state. As such, modernist-reformist Muslims position themselves between "integralists" and "secularists", as balancing purity with reform. As such, modernist-reformist Muslims is often identified as moderate (wasathiyyah) Muslims or-borrowing from the Qur'an-the middle people (ummatan wasathan). They practice this ideology in their social lives, practicing a flexible Islam that recognizes plurality and avoids radicalism. ${ }^{37}$

In moderate Islam, Muslims are understood as muqtasyid (middle people) who practice balance and justice in their everyday lives. ${ }^{38}$ In other words, moderate Islam consistently takes the middle road in religious affairs and avoids exceeding, reducing, or ignoring religious doctrines. ${ }^{39}$ This can be manifested in various ways, including through, first, moderate beliefs; second, eased regulations and obligations; third, broad definitions of regulations and obligations; fourth, openness to emergency prayers (rukhsah); fifth, continuity in worship (without consideration of frequency); sixth, moderation in social interactions and behaviors; and seventh, moderation in the enforcement of regulations. ${ }^{40}$

From the above characteristics, we can see that the moderate Islam practiced by Muhammadiyah is not without its own stance, its own beliefs, its own attitudes, and its own problems that remain open to criticism. In Islam, as in all elements of human life, there is no one interpretation whose truth can be admitted universally; there remain differences in its practice and its implementation, and these different approaches must be recognized and accepted. Haedar Nashir, the Chairman of Muhammadiyah's Central

${ }^{37}$ Nashir, Muhammadiyah Gerakan Pembaruan..., 147.

${ }^{38}$ The Quran sura Luqman: 19 and 32; Al-Maidah: 66; Al-Nahl: 9; Al Taubah: 42; AlFurqan: 67; Al-Qashash: 77; Al-Baqarah: 201-202.

${ }^{39}$ Nashir, Muhammadiyah Gerakan Pembaruan..., 149.

${ }^{40}$ Muhammad Al-Zuhaili, Moderat dalam Islam, Jakarta: Akbar Media Eka Sarana, 2005, 195. 
Leadership Committee, described moderate Islam as follows:

"Moderate Islam is an Islam that doesn't lean to the right or to the left. It exists in the middle, between the extreme right and the extreme left. Any extremes, to the right or the left, do not reflect the theological views of Muhammadiyah. Muhammadiyah does not desire to be to the extreme left or the extreme right, but to remain in the middle (wasathiyyah)". ${ }^{41}$

From a moderate perspective, it is necessary to conduct tajdid (renewal, revival) and interpret the sacred texts (both the Quran and the Sunnah), as well as the teachings of the prophets from Adam to Muhammad. Moderation thus gives Muslims the authority to adapt dynamically and contextually. The only absolute truth is the Quran; the hadiths, the deeds of the Prophet Muhammad, are open to interpretation.

For Muhammadiyah, moderate Islam is a means of realizing the khaira ummah described in Verse 110 of Surah al-Baqarah. It refers to a way of being Muslim without being excessive, i.e. without becoming radical, fundamentalist, or extremist in one's conservativism, secularism, or other ideology. Moderate Islam is not the practice of Islam without principles, but rather the flexible practice of Islam values in accordance with the principle of dakwah Islam bil hikmah (wise and intelligent proselytization), dakwah bil mauidhal hasanah (teaching well), and wa jadil hum bilati hiya ahsan (creating good dialog and arguments). It seeks not competition, but collaboration..$^{42}$

In accordance with this principle, Muhammadiyah does not orient itself

${ }^{41}$ Original: Islam Moderat itu bangunan Islam yang tidak cenderung ke kanan atau ke kiri. Dia berada di tengah-tengah antara ekstremisme kanan dan ekstremisme kiri. Sesuatu yang terlampau ekstrem baik ke kanan atau kekiri itu kurang sesuai dengan pandangan teologi Muhammadiyah. Muhammadiyah tidak berkeinginan menjadi ekstrem kanan atau ekstrem kiri tetapi tetap berada di tengah (wasathiyyah). Interview with Haedar Nashir, Chairman of Muhammadiyah, on September 26, 2019.

${ }^{42}$ Nashir, Muhammadiyah Gerakan Pembaruan..., 149. 
towards obtaining political power (as opposed to other Islamic movements in Indonesia). In other words, it does not desire to shape the national ideology; rather, it seeks solely to spread Islamic teachings and values as a means of promoting justice and prosperity in a society that has been blessed by God. Muhammadiyah da'wah is a mission of humanity, in contrast to political Islamic group in Aksi Bela Islam (Action of Defending Islam), for instance. ${ }^{43}$ Recognizing the recent tendency for Indonesian Muslims to quickly judge others and brand them as deviant, moderate Islam promoted by Muhammadiyah is particularly relevant.

\section{Creating Sunni-Shia dialog}

The Sunni-Shia divide has widely been discussed in the literature, and mutakallimun have contrasted their ideologies and politics ever since these two denominations emerged. However, when schism first occurred, Sunnis and Shiites were not quick to brand each other as deviant; rather, they recognized themselves as having different perspectives regarding the succession to the Prophet Muhammad. Sunnis believed that Abu Bakr was the rightful successor while Shiites held that Ali RA had been appointed by the Prophet. This became increasingly problematic after many of the Prophet's companions were killed in the battles of Siffin and Jamal.

As a result of this history, Sunnis and Shiites have held contrasting theological and political perspectives since the time of the Muawiyah and Abbasid caliphates. However, in Indonesia, the Sunni-Shia divide was rarely framed as a theological or political problem. Through Indonesia's first six decades as an independent nation, theologists, fikh scholars, and political scientists rarely discussed the matter. ${ }^{44}$ However, since the dawn of the new

\footnotetext{
${ }^{43}$ Muzayyin Ahyar dan Alfitri Alfitri, "Aksi Bela Islam: islamic clicktivism and the new authority of religious propaganda in the millennial age in Indonesia," Indonesian Journal of Islam and Muslim Societies, Volume 9, Number 1 (2019), 1-29.

${ }^{44} \mathrm{M}$. Khusna Amal, "Anti-Shia mass mobilization in Indonesia's democracy: godly alliance,
} 
millennium Shia Islam has become a hot-button topic in Sunni-majority Indonesia. Although this has been mostly political in nature, much debate has centered around perceived differences in these denominations' teachings and doctrines. This discourse has failed to recognize that Shiites and Sunnis share an understanding of most religious doctrines, focusing instead on differences in their views of imamate and justice.

From a political perspective, imamate and justice intrinsically involve questions of leadership and social welfare, of society and state. Shias hold that unjust leadership is wrongful leadership and requires all social (or state) leaders to embody the very principle of justice. Only through such leadership can prosperity be realized and human beings receive divine grace. Consequently, one can only be deemed worthy of leadership through provably just behavior and beliefs. ${ }^{45}$ How has Muhammadiyah, through its progressive Islam, responded to this issue? The organization has held that immediate response is necessary. It has recognized that, although conflicts between Sunnis and Shiites in Indonesia have been limited to the local level (as seen in Bandung, Madura, and Makassar), these conflicts are inexorably linked to domestic and international political conflicts and economic disparities. As such, it has urged Muslims to initiate productive dialog, which is necessary to create mutual understanding of and respect for their differences and similarities. Furthermore, it has sought to create awareness that Sunnis and Shiites have shaped Islamic civilization through their lengthy history of collaboration, and as such Sunnis and Shiites must put aside their differences and work together for a brighter future. ${ }^{46}$

Muhammadiyah has asked Indonesian Muslims to act wisely, to respect all

militant groups and the politics of exclusion”, Indonesian Journal of Islam and Muslim Societies, Vol. 10, No. 1 (2020), 25-48.

45Jalaluddin Rakhmat, Akhlak Lebih Dahulu Baru Fikih, Jakarta: Mizan, 2014, 90.

${ }^{46}$ Pimpinan Pusat Muhammadiyah, "Tanfidz Keputusan Muktamar Muhammadiyah ke47”, Berita Resmi Pimpinan Pusat Muhammadiyah (Makassar, 2015), 114. 
of the Prophet Muhammad's companions and family, and to adhere firmly to their faith. With one of the world's largest Muslim populations, Indonesia must initiate dialog and offer itself as a mediator. As the introduction of outside conflicts into Indonesia could threaten the unity of the ummah and the nation, thereby weakening on the global stage, it is necessary for the Indonesian government to spearhead dialog and create active and free political participation. Only then can world peace be made a reality. ${ }^{47}$

If left unaddressed, frictions between Indonesia's Sunnis and Shiites can create significant social and political problems, as they are indicative of problems in majority-minority relations. Indonesia's Sunni majority must recognize religious minorities, such as Shiites as their "travelling companions," as people who share the same goals. Such a view was mentioned by Najib Burhani, who argued that-as Indonesia's religious majorities and minorities are equally citizens-they have the right to be treated justly and without discrimination. ${ }^{48}$ Similarly, Ahmad Syafii Maarif, the former chairman of Muhammadiyah's Central Leadership Committee, stated that:

"Muhammadiyah does differ from Shia. However, Muhammadiyah does not brand Shiites as deviants, let alone unbelievers. Although their theology may differ from that of Muhammadiyah, that is their belief. We at Muhammadiyah need not view Shiites as our enemies". 49

From this discussion, it is clear that Muhammadiyah, as an organization that promotes progressive Islam, has its own particular theological and political perspective regarding religious minorities (in this case, Shiites) and

${ }^{47}$ Azaki Khoiruddin and Andar Nubowo (eds.), Islam Berkemajuan untuk Peradaban Dunia: Refleksi dan Agenda Muhammadiyah ke Depan, Bandung: Mizan, 2015, 332.

${ }^{48}$ Ahmad Najib Burhani, Menemani Minoritas: Paradigma Islam tentang Keberpihakan dan Pembelaan Kepada yang Lain, Jakarta: Gramedia, 2019, 3-13.

${ }^{49}$ Original: "Syiah itu memang berbeda dengan Muhammadiyah. Namun Muhammadiyah tidak serta merta menghukum Syiah sebagai kelompok Islam yang sesat, apalagi mengkafirkan. Secara teologis memang mungkin berbeda dengan Muhammadiyah tetapi itulah keyakinan para penganut Syiah. Kita Muhammadiyah tidak perlu bermusuhan dengan Syiah". Interview with Ahmad Syafii Maarif, Former Chairman of Muhammadiyah, on August 23, 2019. 
the need to create dialogue. It recognizes that foreign political conflicts and economic disparities can disrupt minority-majority relations in Indonesia and threaten national unity.

\section{Substantializing religious dimension}

In discussing the substantializing of Islam, it is necessary to recognize that Islam is not only formalistic, consisting of religious rituals, such as prayers and alms, but it also contains and conveys particular values. In its official statement "Pernyataan Pikiran Muhammadiyah Abad Kedua Puluh" (Muhammadiyah Thought in the 20th Century), the organization identified itself as an Islamic movement with the dual missions of dakwah and tajdid as well as the goal of realizing an Islamic society that has been truly blessed by God (baldah tayyibah wa rabb ghafür). Islamic values are foundational, lying at the basis of the organization and its movement. It believes that Islam and its teachings, having been passed through generations of prophets, are a comprehensive and perfect religion that provides humanity with specific guidelines and prohibitions that guarantee worldly security and heavenly salvation..$^{50}$

Furthermore, Muhammadiyah believes that Islam embodies progressive values that can promote enlightenment. From an Islamic perspective, progress is that which promotes the physical and spiritual betterment of humanity. Dakwah and tajdid, meanwhile, are the channels through which Muhammadiyah can effect change and realize Islam as a blessing for all of Creation. Islam is not static, but rather ever developing and evolving (din al-hadarah). ${ }^{51}$

In its activities, Muhammadiyah has emphasized the importance of maintaining the nation and the state even amidst ideological contestation.

\footnotetext{
${ }^{50}$ Nashir, Memahami Ideologi Muhammadiyah..., 53.

${ }^{51}$ Nashir, Memahami Ideologi Muhammadiyah..., 53.
} 
It firmly holds that the Unitary Republic of Indonesia, as proclaimed on August 17, 1945, is simultaneously a national consensus (där al-ahd) that unites all elements of society and proof of the power of such unity (darr al-shahādah). This reflects the universality inherent in verse 13 of Surah al-Hujurat, which reads "we have created you from male and female and made you peoples and tribes that you may know one another. Indeed, the most noble of you in the sight of Allah is the most righteous of you. Indeed, Allah is Knowing and Acquainted". 52

Islam is not merely a lifestyle, but a philosophy of life. The essence of Islam (the substance of its teachings) is more important than its performance. These teachings-that for instance individual piety affects social piety-offer a means of eradicating poverty and defending against superstition. Islam rejects excessive political desire and corruption, teaching instead that we must live together and help others. As such, Muhammadiyah emphasizes the substance and essence of Islam over performances of piety..$^{53}$

From the above discussion, it is clear that Muhammadiyah-in its Islamic practice-has emphasized the substance of Islam (i.e. its teachings and doctrines) over its formalistic aspects and rituals. For Muhammadiyah, progressive Islam is not performance or a lifestyle, but rather an understanding of Islam that advances progressive and transformative values. Piety does not stop at the individual level; it has wide reaching effects on society and on humanity. In substantializing Islam, as such, it advances an understanding of progressive Islam that incorporates both individual and social piety. It believes that the essence of Islam lies in its values of simplicity, discipline, wisdom, mutual assistance, community, and

\footnotetext{
${ }^{52}$ Pimpinan Pusat Muhammadiyah, Indonesia Berkemajuan: Rekonstruksi Kehidupan Kebangsaan Yang Lebih Bermakna, Yogyakarta: PP Muhammadiyah, 2015, 6.

${ }^{53}$ Pimpinan Pusat Muhammadiyah, "Tanfidz Keputusan Muktamar Muhammadiyah Ke47”, Berita Resmi Pimpinan Pusat Muhammadiyah, 2015, 115.
} 
brotherhood of mankind; both individual and social piety are necessary to teach salvation. As such, Muhammadiyah believes that a sense of community is central to the practice of Islam.

\section{Increasing Muslims' competitiveness}

It has been estimated that $88.6 \%$ (233.2 million) of Indonesia's 265 million residents are Muslim (BPS, 2018). According to the National Development Planning Agency, this population is split approximately evenly, with 133.17 million men and 131.88 million women. In terms of age, this population consists of 70.49 million children (age $0-14 ; 26.6 \%$ ), 179.13 million people of productive age (age 14-64; 67.6\%), and 85.89 million seniors (age 65 and older; 5.8\%). Although Indonesia is not a religious state, religious values remain important in the state and in its governance. Based on this fact, Muhammadiyah assumes that Indonesia is an Islamic society in the country with the largest Muslim population, not an Islamic state since the Unitary State of the Republic of Indonesia chose Pancasila as its foundation based on the agreement of the nation's founders. ${ }^{54}$ In order words, Pancasila is a national consensus between all elements of the nation in the archipelago. ${ }^{55}$

Muhammadiyah recognizes Indonesia as an Islamic society. It acknowledges that, although the country is not an Islamic state, and that its founders agreed on Pancasila as the national ideology, Indonesia is the largest Muslim-majority country on Earth. ${ }^{56}$ Given this sizable Muslim population, Muhammadiyah cannot ignore the real conditions experienced by Indonesians. Muhammadiyah has therefore sought to

\footnotetext{
${ }^{54}$ Haedar Nashir, Gerakan Islam Syariah: Reproduksi Salafiyah Ideologis di Indonesia, Bandung: Mizan, 2013, 204.

${ }^{55}$ Ahmad Najib Burhani, Islam Nusantara as a Promising Response to Religious Intolerance and Radicalism, Singapore: ISEAS-Yus of Ishak Institute, 2018, 1-39.

${ }^{56}$ Haedar Nashir, Gerakan Islam Syariah..., 204.
} 
alleviate the suffering of Muslims who have continued to experience significant shortcomings. Despite their significant population, Indonesian Muslims are unable to compete with the peoples in more technologically, ideologically, and economically developed nations without hard word and structured effort. As such, Muhammadiyah has sought to improve Muslims' ability to compete on the world stage by providing them with the knowledge they need to escape poverty, ignorance, and backwardness. ${ }^{57}$ Central to its endeavors have been programs that teach skills, improve competencies, and establish networks.

Muhammadiyah has also sought to eradicate the practice of blaming others for failure. The blaming of others for one's own mistakes, as well as to conceal one's own shortcomings, is not taught by Islam. Finding fault in others while ignoring one's own faults is the practice and mentality of cowards and hypocrites. Through this mentality, Indonesian Muslims have become a majority with minority mentality complex; in other words, Indonesian Muslims have experienced an inferiority complex. As such, they do not become their own subjects, but remain easily swayed by outside influences. $^{58}$

Within this context, Muhammadiyah recognizes no difference in the piety, religious authority, and social position of Arabs and non-Arabs. All Muslims are the same in the eyes of God. Likewise, in matters of humanity and congregation, one excels not through one's race, but rather one's contributions to the eradication of poverty and other social ailments. In this, Ahmad Syafii Maarif argues that Muslims cannot simply blame others, be they Christians, Jews, Hindus, Buddhists, or Confucians, for their own shortcomings. Likewise, Muslims cannot simply attribute their

\footnotetext{
${ }^{57}$ Pimpinan Pusat Muhammadiyah, "Tanfidz Keputusan Muktamar Muhammadiyah Ke-47”..., 115.

${ }^{58} \mathrm{Ahmad}$ Syafii Maarif, Islam dalam Bingkai Keindonesiaan dan Kemanusiaan: Sebuah Refleksi Sejarah. Bandung: Mizan, 2015, 254.
} 
failings to people of other nationalities; Indonesians, for example, may not simply blame non-Indonesians (the Chinese, the Malays, the Israelis, the Europeans, the Americans) for Indonesia's problems. ${ }^{59}$

Muslims, both in Indonesia and around the world, can only realize their excellence when they are scientifically and technologically competitive. If Muslims have a good command of science and technology, they will be respected by others. Conversely, if they are unable to compete, Muslimsagain, both in Indonesia and around the world-will continue to suffer. Progress cannot be realized without knowledge, science, and technology, which are likewise necessary for advancing civilization. ${ }^{60}$

Such a view has also been maintained by Asyiyah, the women's branch of Muhammadiyah. Aisyiyah has urged Muslim women to continuously improve the quality of their religious, economic, political, and cultural activities, thereby enabling them to utilize their numerical superiority to determine the fate of the nation and of humanity. In this, family and educational institutions are central for spreading progressive Islamic values and implementing strategies. ${ }^{61}$ As with the Muhammadiyah Central Leadership Committee, the Aisyiyah Central Leadership Committee has incorporated progressive Islam in its strategic agendas. In a meeting in Makassar, both organizations recognized progressive Islam as necessary for improving knowledge and advancing both the nation and humanity itself. As such, they have sought to increase Muslims' ability to compete on the world stage not through party politics, but through education and socio-cultural activities. Both Aisyiyah and Nasyiatul Aisyiyah as Muhammadiyah's autonomous organizations are engaged in the realm

${ }^{59}$ Ahmad Syafii Maarif, Krisis Arab dan Masa Depan Dunia Islam, Yogyakarta: Bentang Bunyan, 2018, 114-120.

${ }^{60}$ Maarif, Krisis Arab..., 189-191.

${ }^{61}$ Pimpinan Pusat Aisyiyah, "Tanfidz Muktamar Aisyiyah Ke-47 di Makassar”, Berita Resmi Pimpinan Pusat Aisyiyah, 2015. 
of social humanity and education ${ }^{62}$

\section{Creating a clean and healthy culture}

For Muhammadiyah, one must live cleanly and healthily, in accordance with Surah al-Qashash, Verse 77, of the Qur'an:

"But seek, through that which Allah has given you, the home of the Hereafter; and [yet], do not forget your share of the world. And do good as Allah has done good to you. And desire not corruption in the land. Indeed, Allah does not like corrupters."

As shown by this verse, human beings cannot find happiness and cannot fulfill their responsibilities-be they to worship God, to respect others, or protect the environment-without physical and spiritual health. As such, all Muslims must know how to become and stay healthy. This is no simple task. It requires effort and guidelines, which may be found in the Qur'an and in the hadiths. As such, human beings must both worship God and follow his guidance. ${ }^{63}$ Health requires a balance between body and soul, physical and spiritual, social and individual, and freedom from sickness, ailment, and want; these all necessitate stability, tranquility (sakinah) and a concern for others (rahmah). Only by being physically and spiritually healthy can a Muslim follow the teachings of Islam and carry out his or her religious obligations; likewise, a Muslim can only realize his or her social duties with a healthy mind and body. Such a principle underlies Muhammadiyah's conceptualization of progressive Islam, through which it urges Muslims to avoid harm and to be blessings unto others. These, it holds, are the only

\footnotetext{
${ }^{62}$ Siti Syamsiyatun, "Muslim Women's Politics in Advancing Their Gender Interests: A Case-Study of Nasyiatul Aisyiyah in Indonesia New Order Era," Al-Jami'ah: Journal of Islamic Studies, Volume 45, Number 1 (2007), 57-89.

${ }^{63}$ Pimpinan Pusat Muhammadiyah, "Tuntunan Keluarga Sakinah, Tanfidz Muktamar Muhammadiyah-Aisyiyah Ke-47, Makassar,” Berita Resmi Pimpinan Pusat Muhammadiyah, 2015, 132.
} 
ways that one can bring oneself closer to the perfection of God. ${ }^{64}$

Islamic teachings of cleanness and sacrality have yet to become part of Muslims' everyday lives. Clean, healthy living, and environmental conservation, have yet to become part of Islamic culture. This is partly because the definition of "clean and healthy living" remains unclear. Islam remains understood predominantly in terms of fiqh (Islamic civil jurisprudence), jinayah (Islamic criminal jurisprudence), hudūd (formal punishments), and worship. As such, the explicit and implicit teachings of healthy living, cleanliness, disaster preparedness, and conservation have long been ignored.

The limited practice of clean and healthy living among Muslims can also be attributed to particular predominant mindsets. As such, it is necessary to make Muslim individuals, families, and communities perceive cleanliness and health as integral to their religion. Take, for example, the purification that Muslims must undergo before worship (including prayer). This necessitates cleanliness (tahärah), which most Muslims continue to understand within the context of the physical. They limit cleanliness to the physical body, environment, family, and community, failing to acknowledge the importance of clean souls, words, actions, and behaviors. ${ }^{65}$

Within this context, Muhammadiyah has published a book titled Fikih Air dan Teologi Lingkungan (Water and Environmental Theology) to guide members in creating a clean and healthy culture. ${ }^{66}$ However, this book is insufficient on its own; it must be accompanied by a widespread advocacy movement oriented towards creating a collective awareness of the need to live cleanly. Only through such a movement can clean and healthy living become a central component of Islamic culture, i.e. be provided more

\footnotetext{
${ }^{64}$ Pimpinan Pusat Muhammadiyah, "Tuntunan Keluarga Sakinah..., 133.

${ }^{65}$ Muhammadiyah, "Tanfidz Keputusan Muktamar Muhammadiyah Ke-47”..., 116.

${ }^{66}$ Jonathan D. Smith, "Connecting Global and Local Indonesian Religious Environmental Movements," Kawistara, Volume 7, Number 3 (2017), 207-25.
} 
than mere lip service, and thereby be practiced in all contexts and in all conditions.

\section{The unification of the Islamic calendar}

Muslims are a people united by their belief in God (ummah wähidah), sharing the same kiblah (direction faced during worship) and the same Creator. However, in their social relations, use of technology, and worship practices, Muslims differ significantly. As such, it is common for Muslims to compete amongst themselves, even though their differences are only "skin deep". Take, for example, the determination of the beginning of the holy month of Ramadhan and of the Eid al-Fitr holiday. ${ }^{67}$ Indonesia's two largest Islamic organizations, Muhammadiyah and NU, have generally celebrated these holidays on different dates; Muslims in the Salafi tradition, meanwhile, tend to choose yet another date. ${ }^{68}$

One main reason for such differences is the lack of a single, unified calendar that can guide Muslims worldwide. Muhammadiyah holds that, if all Muslims shared a singular calendar, such differences of opinion could be minimized and Muslims could dedicate their energies towards essential matters. Through its method of hizab (astronomy), the organization has the potential to offer a singular Islamic calendar that minimizes disagreement. ${ }^{69}$ Muhammadiyah hopes that, through progressive Islam, Muslims can learn to think far into the future and to be ready to adapt to technological and scientific advances. This necessitates a willingness to accept new knowledge and different perspectives. In their quest to

${ }^{67}$ Musa Al-Azhar, "Kalender Hijriyah dalam Al-Qur'an", Al-Marshad: Jurnal Astronomi Islam dan Ilmu-Ilmu Berkaitan, Volume 4, Nomor 2 (2018), 227-241.

${ }^{68}$ Alexander R. Arifianto, "Rising Islamism and the Struggle for Islamic Authority in PostReformasi Indonesia”, TRaNS: Trans-Regional and-National Studies of Southeast Asia, (2019), 1-14.

${ }^{69}$ Susiknan Azhari, "Gagasan Menyatukan Umat Islam Indonesia Melalui Kalender Islam”, Ahkam, Volume XV, Nomor 2 (2015), 249-258.; Rupiâ Amri, "Pemikiran Mohammad Ilyas tentang Penyatuan Kalender Islam Internasional,” Profetika, Volume 17, Nomor 1 (2016), 1-15. 
compete internationally, Muslims cannot ignore their thirst for knowledge. They cannot be mere consumers; they must become producers of modern science and technology. Regarding the creation of a shared Islamic calendar, Oman Faturrahman-a member of the Muhammadiyah Central Leadership Committee's Joint Assembly-explained:

"Muslims need to have a shared calendar, so that we no longer differ in when we start our years. Because we have no shared calendar, we Indonesians frequently differ in our expression and celebration of Ramadhan, Syawal, and Eid al-Adha. We can reduce this if we in Indonesia, or even around the world, shared a single Islamic calendar ". 70

For this purpose, Muhammadiyah has sought to use progressive Islam to advocate for reform. It has recognized the crucial problems facing humanity, as well as the need to adapt new sciences and technologies and use them appropriately. ${ }^{71}$ However, all of this must be understood as part of proselytization, a process through which tadjid (reform) can be actualized in Islamic, national, humanitarian, and congregational life. It is in this manner that progressive Islam can produce a prosperous and just society that is blessed by God (baldatun tayibatun wa rabun ghafur), thereby realizing the founders' vision for the Unitary Republic of Indonesia.

Recognizing the importance of its agendas and its decrees, in 2005 Muhammadiyah discussed the theme of Achieving the Primacy of Civilization during its 45th national congress. Muhammadiyah recognizes that, as a major Islamic organization, it must contribute to the advancement

70"Umat Islam ini perlu memiliki kesatuan kalender hijriyah sehingga tidak terjadi perbedaan penentuan awal bulan hijriyah. Akibat tidak adanya kesatuan kalender hijriyah maka di Indonesia pun sering terjadi perbedaan penentuan awal bulan Ramadhan dan Syawal serta Idul Adha. Hal ini akan terkurangi jika ada kesatuan kalender Hijriyah dikalangan umat Islam Indonesia apalagi dunia”. Interview with Oman Faturrahman, member of the Muhammadiyah Central Leadership Committee's Joint Assembly, on August 7, 2019.

${ }^{71}$ Ryan McKay dan Harvey Whitehouse, "Religion and morality", Psychological Bulletin, Volume 141, Number 2 (2015), 447-743. 
of the ummah and general humanity at the local, national, regional, and international level. As such, it has tirelessly advocated for the purification of Islamic teachings, development of Islamic thought, implementation of social welfare, and teaching of an Islamic character. In these efforts, Muhammadiyah's main focus has been creating a new culture that can protect the welfare of the nation, the ummah, and humanity.

Given that Muhammadiyah dealt with the theme of Progressive Islam for National Civilization in its 2015 National Congress in Makassar, the organization may be identified as acting at all levels to promote worldly welfare and spiritual glory. It seeks to balance individual and social life in steadfastness (istiqomah), to advocate for dedication to God and to society. It has sought to realize the message of Surah al-Ma'un, verses 104 and 110, which it identifies as part of its foundational principles, and to ensure that Indonesian Muslims reflect these principles in their everyday lives.

At the international level, meanwhile, Muhammadiyah has sought to promote global peace. For example, it has contributed to peace talks in the South Philippines, South Thailand, and Middle Eastern countries such as Iran and Saudi Arabia by holding international meetings of ulama (Islamic scholars). It has thus offered its vision of progressive Islam to the ummah and the world. Muhammadiyah has desired to create world peace, welfare, and social justice for all. In this vein, and despite its shortcomings, it has provided its services to all who need them-even non-Muslims. It views such services as part of its incessant struggle to advocate for social betterment. Being Muhammadiyah and advancing progressive Islam is no easy task; it requires worldly endeavors and commitment. It requires a willingness to compromise, to be humble, and to acknowledge that all people contribute in their own way. It is for this reason that the progressive Islamic ideology is deemed one of submissiveness. ${ }^{72}$

\footnotetext{
${ }^{72}$ Haedar Nashir, Kristalisasi Ideologi dan Komitmen Bermuhammadiyah, Yogyakarta: Suara
} 


\section{Conclusion}

From this discussion of progressive Islam within the context of the ummah and of world civilization, two main conclusions may be drawn. First, through its ideology of progressive Islam, Muhammadiyah seeks to provide enlightenment (tanwir) to the Muslims of Indonesia, especially its members, and teach them to deal with the matters of the ummah. Muslims have focused on the formal, rather than the substantial, and this requires the concern of Islamic scholars, proselytizers, and organizations. While acknowledging the importance of the formal aspects of religion, it urges Muslims to embrace the substance of their religious teachings and to embody the 'spirit' of Islam. Only then can they transform the formalistic worship of God (habl min Allah) into the comprehensive implementation of Islamic teachings (habl min al-nas).

Second, progressive Islam-as part of the enlightenment (tanwir) of humanity-deals with such universal matters as peace, social justice, and the betterment of humanity. Only by concerning themselves with such matters, and by improving the quality of their human resources, can Muslims contribute to their nation and compete with others on the world stage. Recognizing this goal is paramount in efforts to improve the quality of Muslims through progressive Islam.

\section{Bibliography}

Abdurrahman, Moeslim. Suara Tuhan Suara Pemerdekaan. Yogyakarta: Kanisius and Impulse, 2009.

Achmadi. Merajut Pemikiran Cerdas Muhammadiyah: Perspektif Sejarah. Yogyakarta: Suara Muhammadiyah, 2010.

Ahyar, Muzayyin dan Alfitri Alfitri, "Aksi Bela Islam: Islamic Clicktivism and the New Authority of Religious Propaganda in the Millennial Age in Indonesia," Indonesian Journal of Islam and Muslim Societies, Volume 9, Number 1 (2019): $1-29$.

Muhammadiyah, 2007, 68-69. 
Amal, M. Khusna, "Anti-Shia mass mobilization in Indonesia's democracy: godly alliance, militant groups and the politics of exclusion", Indonesian Journal of Islam and Muslim Societies, Vol. 10, No. 1 (2020): 25-48.

Al-Azhar, Musa, "Kalender Hijriyah Dalam A-Qur'an," Al-Marshad: Jurnal Astronomi Islam dan Ilmu-Ilmu Berkaitan, Volume 4, Nomor 2 (2018): 227-241.

Al-Zuhaili, Muhammad. Moderat Dalam Islam, ed. by Ahmad Yunus Naidi. Jakarta: Akbar Media Eka Sarana, 2005.

Amri, Rupiâ, "Pemikiran Mohammad Ilyas Tentang Penyatuan Kalender Islam Internasional," Profetika, Volume 17, Nomor 1 (2016): 1-15.

Arifianto, Alexander R., "Rising Islamism and the Struggle for Islamic Authority in Post-Reformasi Indonesia”, TRaNS: Trans-Regional and -National Studies of Southeast Asia, (2019):1-14.

Azhar, Susiknan, "Gagasan Menyatukan Umat Islam Indonesia Melalui Kalender Islam”, Ahkam, Volume XV, Nomor 2 (2015): 249-258.

Burhani, Ahmad Najib. Menemani Minoritas: Paradigma Islam tentang Keberpihakan dan Pembelaan Kepada yang Lain. Jakarta: Gramedia, 2019.

Burhani, Ahmad Najib. Muhammadiyah Berkemajuan: Pergeseran dari Puritanisme ke Kosmopolitanisme. Bandung: Mizan, 2016.

Burhani, Ahmad Najib. Islam Nusantara as a Promising Response to Religious Intolerance and Radicalism. Singapore: ISEAS-Yusof Ishak Institute, 2018: $1-39$.

Burhani, Ahmad Najib, "Liberal and conservative discourses in the Muhammadiyah: The struggle for the face of reformist Islam in Indonesia", in Contemporary Developments in Indonesian Islam: Explaining the 'Conservative turn', Martin van Bruinessen (ed.), Singapore: ISEAS-Yusof Ishak Institute, 2013: 105-144.

Gada, Mohd Yaseen. "On Pluralism, Religious 'other', and the Quran: a post September-11 Discourse," Indonesian Journal of Islam and Muslim Societies, Volume 6, Number 2 (2016), 241-71.

Haar, Gerrie ter, and James J Bussuttil. The Freedom to Do God's Will: Religious Fundamentalism and Social Change. London and New York: Routledge, 2003.

Huda, Syamsul. "The Local Construction of Religious Blasphemy in East Java," Journal of Indonesian Islam, Volume 13, Number 1, (June 2019), 96-114-75. Johnston, Hank, "Identities, Grievances, and New Social Movements", in New Social Movements: From Ideology to Identity, ed. by Enrique Larana, Hank Johnston, and Joseph R Gusfield. USA: Temple University Press, 1994. 
IJIMS: Indonesian Journal of Islam and Muslim Societies, Volume 10, Number 2, December 2020: 323-352

Latief, Hilman. Melayani Umat: Filantropi Islam dan Ideologi Kesejahteraan Kaum Modernis. Jakarta: Gramedia and Maarif Institute, 2010.

Latief, Hilman. Post-Ouritanisme: Pemikiran dan Arah Baru Gerakan Islam Modernis di Indonesia, 1995-2015. Yogyakarta: LP3M Universitas Muhammadiyah Yogyakarta, 2017.

Maarif, Ahmad Syafii. Islam dalam Bingkai Keindonesiaan dan Kemanusiaan: Sebuah Refleksi Sejarah. Bandung: Mizan, 2015.

Maarif, Ahmad Syafii. Krisis Arab dan Masa Depan Dunia Islam. Jakarta: Bentang Bunyan, 2018.

McKay, Ryan dan Harvey Whitehouse, "Religion and Morality," Psychological Bulletin, Volume 141, Number 2 (2015): 447-473.

Mulkhan, Abdul Munir. Marhaenis Muhammadiyah. Yogyakarta: Galang Press, 2010.

Nakamura, Mitsuo. The Crescent Arises over the Banyan Tree: A Study of the Muhammadiyah Movement in a Central Javanese Town, c.1910s-2010: 2nd Enlarged Edition. Singapore: Institute of Southeast Asian Studies, 2012.

Nubuwo, Khoiruddin dkk. Islam Berkemajuan untuk Peradaban Dunia: Refleksi dan Agenda Muhammadiyah ke Depan. Bandung: Mizan, 2015.

Nashir, Haedar et al., "Muhammadiyah's Moderation Stance in the 2019 General Election: Critical Views from Within," Al-Jami'ah: Journal of Islamic Studies, Volume 57, Number 1, (June 2019): 1-24.

Nashir, Haedar. Gerakan Islam Syariah: Reproduksi Salafiyah Ideologis di Indonesia. Bandung: Mizan, 2013.

Nashir, Haedar, "Islam Berkemajuan dan Aktualisasi Gerakan Muhammadiyah", in Islam Berkemajuan Untuk Peradaban Dunia: Refleksi dan Agenda Muhammadiyah, ed. by Alpha Amirrachman, Andar Nubowo, and Azaki Khoiruddin. Bandung: Mizan, 2015.

Nashir, Haedar. Islam Syariat: Reproduksi Salafiyah Ideologis di Indonesia. Bandung: Mizan-Maarif Institute, 2013.

Nashir, Haedar. Kristalisasi Ideologi dan Komitmen Bermuhammadiyah. Yogyakarta: Suara Muhammadiyah, 2007.

Nashir, Haedar. Memahami Ideologi Muhammadiyah. Yogyakarta: Suara Muhammadiyah, 2014.

Nashir, Haedar. Muhammadiyah Gerakan Pembaruan. Yogyakarta: Suara Muhammadiyah, 2010.

Nubowo, Andar, Azzaki Khoiruddin (ed.). Islam Berkemajuan untuk Peradaban 
Dunia: Refleksi dan Agenda Muhammadiyah ke Depan. Bandung: Mizan, 2015. Oliver, Pamela E, and Daniel J Myers. "Formal Models in Studying Collective Actions and Social Movement", in Method of Social Movement Research, ed. by Bert Klandermans and Suzanne Staggenborg. Minneapolis: University of Minnesota Press, 2002.

Pimpinan Pusat Muhammadiyah. Indonesia Berkemajuan: Rekonstruksi Kehidupan Kebangsaan yang Lebih Bermakna, 2015.

Pimpinan Pusat Muhammadiyah, "Tanfidz Keputusan Muktamar Muhammadiyah Ke-47”, Berita Resmi Pimpinan Pusat Muhammadiyah, 2015.

Pimpinan Pusat Aisyiyah, "Tanfidz Muktamar Aisyiyah Ke-47 di Makassar", Berita Resmi Pimpinan Pusat Aisyiyah, 2015.

Porta, Donatella Della. Methodological Practices in Social Movement Research. Oxford: Oxford University Press, 2014.

Qodir, Zuly, "Muhammadiyah Sebagai Gerakan Sosial Baru: Inspirasi Menuju Masyarakat Berkemajuan", in Islam Berkemajuan Untuk Peradaban Dunia: Refleksi dan Agenda Muhammadiyah ke Depan, ed. by Alpha Amirrachman, Andar Nubowo, and Azaki Khoiruddin. Bandung: Mizan, 2015.

Qodir, Zuly, "Kalibokong Theology' and Moeslim Abdurrahman's Transformative Islamic Education," Iseedu: Journal of Islamic Educational Thoughts and Practices, Volume 1, Number 1 (2017): 23-46.

Rakhmat, Jalaluddin. Akhlak Lebih Dahulu Baru Fikih. Bandung: Mizan, 2014.

Ricklefs, M. C., Islamisation and Its Opponents in Java: A Political, Social, Cultural and Religious History, c. 1930 to the Present. Singapore: NUS Singapore, 2012.

Safi, Omid. Progressive Muslims: On Justice, Gender, and Pluralism. England: Oneworld Oxford, 2003.

Saifullah. Gerak Politik Muhammadiyah dalam Masyumi. Jakarta: Grafiti Press, 1997. Saifullah. Pergeseran Politik Muhammadiyah. Yogyakarta: Pustaka Pelajar, 2015.

Saleh, Fauzan. Teologi Pembaruan: Pergeseran Wacana Islam Sunni di Indonesia Abad XX. Jakarta: Serambi, 2004.

Shihab, Alwi. "Membendung Arus, Respons Muhammadiyah terhadap Penetrasi Kristen di Indonesia", Suara Muhammadiyah, 2016: 260-270.

Singh, Rajendra. Social Movements, Old and New: A Post-Modernist Critique. USA and London: Sage Publication, 2001.

Smith, Jonathan D. "Connecting Global and Local Indonesian Religious Environmental Movements," Kawistara, Volume 7, Number 3 (2017): 207-25. 
IJIMS: Indonesian Journal of Islam and Muslim Societies, Volume 10, Number 2, December 2020: 323-352

Sunesti, Yuyun, Noorhaidi Hasan, and Muhammad Najib Azca, 'Young SalafiNiqabi and Hijrah:Agency and Identity Negotiation', Indonesian Journal of Islam and Muslim Societies, Volume 8, Number 2 (2018): 173-97.

Syamsiyatun, Siti. "Muslim Women's Politics in Advancing Their Gender Interests: A Case-Study of Nasyiatul Aisyiyah in Indonesia New Order Era," Al-Jami'ah: Journal of Islamic Studies, Volume 45, Number 1 (2007): 57-89. 